\title{
8. Lærerkompetanse, undervisningskvalitet og naturfagprestasjoner fra TIMSS 2015 til TIMSS 2019
}

\section{Hege Kaarstein og Trude Nilsen}

Sammendrag Lærernes kompetanse og undervisningskvalitet har betydning for elevenes prestasjoner, mens elevsammensetningen i en klasse har betydning for både undervisningskvalitet og prestasjoner. Dette kapitlet undersøker om endringer i disse variablene kan forklare nedgangen i naturfagprestasjoner på 9. trinn fra TIMSS 2015 til TIMSS 2019. Resultatene fra en kvasi-longitudinell metodisk tilnærming med medieringsmodellering tyder på at lærerne har vært med på å motvirke nedgangen i naturfagprestasjoner, mens elevfaktorer som begrenser undervisningskvaliteten, kan ha sammenheng med nedgangen.

Nøkkelord TIMSS | lærerkompetanse | undervisningskvalitet | naturfagprestasjoner I elevfaktorer som begrenser undervisningskvalitet I trendanalyser

\begin{abstract}
Teacher quality and instructional quality is related to student achievement, while student composition of a class is related to both instructional quality and student achievement. This chapter investigates if changes in these variables can explain the decline in science achievement at Grade 9 from TIMSS 2015 to TIMSS 2019. The results from a quasi-Iongitudinal approach with mediation modeling, indicates that teachers reduces the decline in science achievement, while student factors limiting the instructional quality to some extent explains the decline.
\end{abstract}

Keywords TIMSS I teacher quality | instructional quality | science achievement | student factors reducing instructional quality I trend analyses 


\subsection{INTRODUKSJON}

Lærerne er skolens viktigste ressurs. Nøkkelen til å løfte kunnskapen blant elevene er å satse på lærernes kompetanse. (Kunnskapsdepartementet, 2014, s. 10)

Sitatet over, fra Kunnskapsdepartementets strategi «Lærerløftet. På lag for kunnskapsskolen», samsvarer godt med det store bildet som fremkommer i forskningslitteraturen - lærernes kompetanse har en positiv påvirkning på elevenes utvikling og læringsutbytte (se f.eks. Blömeke, 2017; Blömeke, Olsen \& Suhl, 2016; Fauth et al., 2019; Kaarstein, Nilsen \& Blömeke, 2016; Nilsen, Scherer \& Blömeke, 2018; Wang \& Degol, 2016; Wayne \& Youngs, 2003), og de norske kompetansekravene for undervisning av fagene i grunnskolen som kom i $2014^{1}$, er en konsekvens av dette (Kunnskapsdepartementet, 2014). Lærernes kompetanse utvikles ikke bare i løpet av den formelle utdanningen, den videreutvikles i daglig praksis og organisert etter- og videreutdanning (EVU), og ifølge tidligere forskning er det en positiv sammenheng både mellom lærernes EVU-aktivitet og elevenes prestasjoner, men også med lærernes undervisningskvalitet (Blömeke, Olsen \& Suhl, 2016; Nilsen et al., 2018; Timperley, Wilson, Barrar \& Fung, 2007). I tillegg til satsingen på å heve lærernes kompetanse via EVU har det også vært satset stort på å heve elevenes kompetanse i og motivasjon for realfag (Kunnskapsdepartementet, 2011, 2015) ${ }^{2}$.

Til tross for denne satsingen viser begge undersøkelsene som følger med på utvikling av norske elevers matematikk- og naturfagkompetanse over tid på ungdomstrinnet (TIMSS ${ }^{3}$ og PISA ${ }^{4}$ ), at det har vært en nedgang i norske elevers naturfagprestasjoner siden 2015 (Jensen et al., 2019; Kaarstein, Radišić, Lehre, Nilsen \& Bergem, 2020). Sammenlignet med prestasjonen til de norske elevene på barnetrinnet i TIMSS og med elevene på ungdomstrinnet i de andre nordiske landene som deltar i TIMSS-undersøkelsen, er de norske prestasjonene i naturfag på ungdomstrinnet lave. I tillegg har de vært lave over lengre tid (se f.eks. Bergem, Kaarstein \& Nilsen, 2016; Grønmo \& Onstad, 2009; Grønmo et al., 2012).

$1 \quad$ For å kunne undervise i norsk, engelsk og matematikk må den som skal undervise i fagene på barnetrinnet, ha minimum 30 relevante studiepoeng og 60 på ungdomstrinnet (se forskrift til opplæringslova \$14,1-3). For å undervise i de andre fagene, deriblant naturfag, på barnetrinnet kreves det ingen studiepoeng, mens kravet på ungdomstrinnet er 30 studiepoeng. 30 studiepoeng tilsvarer et halvt års fulltidsstudium ved høgskole eller universitet.

2 Se også oversikt over nasjonale realfagssatsinger og ressurser på udir.no.

3 TIMSS - Trends in International Mathematics and Science Study, se f.eks. timss.no eller timssandpirls.bc.edu.

4 PISA - Programme for International Student Assessment, se f.eks. pisa.no eller oecd.pisa. 
Kunnskap om årsaker til nedgang er viktig informasjon dersom det skal settes inn målrettede tiltak. Eksempelvis vil det være viktig at både den initiale lærerutdanningen og EVU-virksomhetene får mer detaljert informasjon om hvilke aspekter av læreres kompetanse som er spesielt viktige for elevers læringsutbytte.

Mye av forskningen på lærernes betydning for elevenes læringsutbytte er utført i Tyskland og USA med matematikk som fokusfag (se f.eks. Baumert et al., 2010; Ferguson \& Danielson, 2015; Hill, Rowan \& Ball, 2005; Kunter et al., 2013). Ifølge Blömeke og Olsen (2019) kan slike funn variere fra land til land, derfor vil det være viktig å se på dette i en norsk sammenheng også, og å fokusere på naturfag. Videre er det slik at tidligere norske undersøkelser om undervisningspraksis og læringsutbytte i naturfag ofte har hatt små eller mellomstore utvalg (se f.eks. Ødegaard et al., 2021), hvilket begrenser muligheten til å generalisere funn. Det er heller ikke mange undersøkelser som både har representativt utvalg og ser på endring over tid.

I den senere tid er det utviklet (kausale) metoder som kan benyttes til å undersøke hvorvidt endringer i én variabel (som f.eks. læreres kompetanse) har en effekt på endringer i elevers prestasjoner (Gustafsson, 2013; Gustafsson \& Nilsen, i trykk; Kaplan \& Jude, i trykk). Ved å ta i bruk disse metodene på TIMSS-data stiller dette kapitlet derfor følgende forskningsspørsmål:

1. Hvordan endrer lærernes kompetanse og undervisningskvalitet seg fra TIMSS 2015 til TIMSS 2019, og kan endringer bidra til å forklare endringen i elevenes naturfagprestasjoner på 9. trinn?

Det vil selvsagt være ulike faktorer som kan påvirke lærernes naturfagundervisning, og en av disse er elevene selv, eller rettere sagt sammensetningen av elever i en klasse. Dersom mange elever i en klasse har utfordringer knyttet til for eksempel språk, atferd, fysisk eller psykisk helse, kan dette både virke begrensende på undervisningen og gå ut over elevenes prestasjoner (Oliver, Wehby \& Reschly, 2011). Derfor inkluderes også forskningsspørsmålet:

2) Hvordan endres begrensninger for undervisningen når det gjelder elevsammensetningen fra TIMSS 2015 til TIMSS 2019, og kan en endring bidra til å forklare endringen i elevenes naturfagprestasjoner på 9. trinn? 


\subsection{TEORETISK BAKGRUNN}

I denne delen gis det en beskrivelse av hva som menes med læreres kompetanse og undervisningskvalitet, hvilke begrensninger som innvirker på undervisningen $\mathrm{i}$ betydningen sammensetningen av elevene i en klasse, og hvordan disse faktorene henger sammen med elevenes læringsutbytte.

\subsubsection{Lærernes kompetanse}

I den internasjonale forskningslitteraturen knyttet til lærernes kompetanse brukes ofte betegnelsen «teacher quality» (se f.eks. Bolyard \& Moyer-Packenham, 2008; Goe, 2007), og svært mange studier viser at dette har en positiv sammenheng med både undervisningen og elevenes prestasjoner (Blömeke, Olsen \& Suhl, 2016; Creemers \& Kyriakides, 2010; Darling-Hammond, 2000; Fauth et al., 2019; Goe, 2007; Hattie, 2012; Nilsen et al., 2018; Rowan, Correnti \& Miller, 2002). «Teacher quality» deles typisk inn i lærernes formelle kvalifikasjoner og profesjonskompetanse (se f.eks. Goe, 2007; Klingebiel \& Klieme, 2016), hvor de formelle kvalifikasjonene består av deres lærerutdanning, hva slags fagspesialisering de har, om de har deltatt i etter- og/eller videreutdanning, og flere regner også inn deres yrkeserfaring som en del av kvalifikasjonene (Goe, 2007; Postholm, 2012; Seidel \& Shavelson, 2007). Profesjonskompetansen inkluderer både kunnskap og ferdigheter (Blömeke, Gustafsson \& Shavelson, 2015) i tillegg til selvtillit knyttet til det å være lærer og deres oppfatning om læring og undervisning (på engelsk ofte omtalt som teacher self-efficacy og beliefs) (Bryan, 2012; Cakiroglu, Capa-Aydin \& Hoy, 2012; Künsting, Neuber \& Lipowsky, 2016; Voss, Kleickmann, Kunter \& Hachfeld, 2013).

Av de mange kunnskapsaspektene som hører inn under en lærers profesjonelle kompetanse, er det to som har fått mye oppmerksomhet i det siste, nemlig faglig og fagdidaktisk kunnskap (Abell, 2008; Baumert et al., 2010). Disse kunnskapstypene er det ikke alltid like lett å måle, men det har vist seg at begge kunnskapstypene kan måles indirekte (Blömeke \& Olsen, 2019; Nilsen et al., 2018; Tatto et al., 2012). Faglig kunnskap kan måles indirekte via lærernes utdanningsnivå, EVUaktivitet og fagspesialisering, og den fagdidaktiske kunnskapen er nært knyttet til lærernes tro på, eller selvtillit knyttet til, egen fagdidaktisk kompetanse (ibid.). Disse indikatorene viser seg også å ha en positiv sammenheng med lærernes undervisningskvalitet (Burić \& Kim, 2020; Gustafsson \& Nilsen, 2016; Kaarstein et al., 2016; Nilsen \& Bergem, 2020; Nilsen et al., 2018; Timperley et al., 2007). 


\subsubsection{Læreres undervisningskvalitet}

Generelt består undervisning av mange forskjellige aspekter, men de aspektene som tidligere forskning peker på for å fremme elevers læringsutbytte, handler om organisering og ledelse av klassen og hvordan lærerne støtter og utfordrer elevene (Kuger, Klieme, Jude \& Kaplan, 2016; Neumann, Kauertz \& Fischer, 2012; Nilsen \& Gustafsson, 2016). I litteraturen omtales og samles disse spesifikke aspektene i begrepet undervisningskvalitet (Baumert et al., 2010; Ferguson \& Danielson, 2015; Klieme, Pauli \& Reusser, 2009; Neumann et al., 2012; Praetorius, Klieme, Herbert \& Pinger, 2018). I europeisk utdanningsforskning deles ofte undervisningskvalitet inn i de tre aspektene støttende loering, hvor lærerne yter både sosial og faglig støtte, kognitiv utfordring, hvor lærerne ønsker at elevene skal strekke seg lenger kognitivt, og klasseledelse (Baumert et al., 2010; Blömeke, Busse, Kaiser, König \& Suhl, 2016; Klieme et al., 2009; Kunter et al., 2013; Neumann et al., 2012).

I en støttende undervisningspraksis handler det om at læreren ser og viser interesse for den enkelte elev og den enkelte elevs læring, at læreren hører på og respekterer elevenes ideer, gir tilbakemeldinger og tilpasser undervisningen (Praetorius, Grünkorn \& Klieme, 2020). Denne praksisen inkluderer også det å hjelpe elevene med å oppsummere hva de har lært, og se sammenhengen mellom tidligere underviste emner og nye. I tillegg vil undervisningen og læringsmålene være klare og tydelige (Cohen \& Grossman, 2016; Nilsen \& Gustafsson, 2016).

En undervisningspraksis hvor elevene utfordres kognitivt, kan for eksempel være knyttet til problemløsing, utforsking, eller det å prøve seg på utfordrende oppgaver (Baumert et al., 2010; Hiebert \& Grouws, 2007; Minner, Levy \& Century, 2010). Her vil elevene blant annet måtte analysere, tolke, integrere, evaluere, resonnere og benytte kunnskapen sin i både kjente og ukjente kontekster.

Klasseledelse er den mest generiske av de tre aspektene som inngår i undervisningskvalitet (Praetorius et al., 2018), fordi aspektet handler om å sørge for gode vilkår for effektiv læring i klasserommet. Det vil for eksempel si å ha kontroll på bråk og uro som kan forstyrre både undervisningen og læringen (Kyriakides, Creemers \& Antoniou, 2009; van Tartwijk \& Hammerness, 2011).

At det er en positiv sammenheng mellom elevers prestasjoner og klasseledelse, er behørig dokumentert i litteraturen (se f.eks. Freiberg, 2013; McGarity Jr. \& Butts, 1984; Oliver et al., 2011). Derfor er støttende loerer og kognitiv utfordring de mest interessante aspektene å forske mer på, da de er nærmere knyttet undervisningen av fag enn klasseledelse.

Når undervisningskvalitet knyttes til elevenes læringsutbytte, vil det variere hvor detaljert en ønsker å være. Relasjonen til elevenes læringsutbytte kan undersøkes for hvert av aspektene som inngår i undervisningskvalitet om en ønsker en mer 
nyansert tilbakemelding, for eksempel på hvilket aspekt som er sterkest knyttet til læringsutbytte. Eller en kan på et mer overordnet nivå se på undervisningskvalitet (samlet) i sammenheng med utbyttet. For dette kapitlet er det, av grunner som forklares nærmere i kapittel 8.3.3, inkludert ett aspekt av undervisningskvalitet i analysene, nemlig støttende loerer.

\subsubsection{Begrensninger for undervisningen - elevsammensetningen}

En lærers undervisningskvalitet vil kunne variere, og den vil være avhengig av elevsammensetningen (Nilsen, Scherer, Gustafsson, Teig \& Kaarstein, 2020; Praetorius et al., 2020). Med det menes at lærernes undervisningspraksis kan variere fra klasse til klasse avhengig av hvilke elever som går i klassen. Det er lett å tenke seg at en lærer i en «snill og stille» klasse vil kunne ha god klasseledelse, og at en støttende undervisningspraksis vil kunne variere med elevenes fysiske, psykiske, kognitive og/eller psykososiale utfordringer. Når elevene møter trøtte eller sultne på skolen, er uengasjerte, eller mangler (grunnleggende) faglig kunnskap de er forventet å inneha, vil dette ha en innvirkning på lærerens undervisningskvalitet (Oliver et al., 2011; Wang \& Degol, 2014). Men det bør også nevnes at undervisningskvaliteten også kan påvirke elevenes engasjement i positiv retning (se f.eks. Quin, Hemphill \& Heerde, 2017).

I tidligere internasjonal forskning på hvilke faktorer i klasserommet som kan hindre god undervisning og læring, er det bred enighet om at elever med atferdsproblemer, eller elever som mangler engasjement, forkunnskaper og ferdigheter, til dels kan gi store utfordringer for læreren i tillegg til at det går ut over elevenes egne prestasjoner (Abebe \& Hailemariam, 2007; Oliver et al., 2011; Wang \& Degol, 2014; Yin \& Fishbein, 2020). Det kan for eksempel oppleves stressende for en lærer at verdifull tid til opplæring blir brukt til å håndtere uønsket atferd hos elevene, eller til å ta igjen / repetere kunnskap elevene egentlig er forventet å inneha. Verdifull undervisningstid kan også gå tapt dersom veldig mange av elevene i en klasse er uengasjerte og mye krefter må brukes på å skape engasjement blant elevene.

Det er imidlertid ikke bare elevenes atferd, engasjement og kunnskapsmangler som kan påvirke undervisningen og elevers prestasjoner negativt. Tidligere studier har funnet en positiv effekt av et sunt kosthold på læring, karakterer, hukommelse og prestasjoner (Burrows, Goldman, Pursey \& Lim, 2017; Hysing, Pallesen, Stormark, Lundervold \& Sivertsen, 2013; Rampersaud, Pereira, Girard, Adams \& Metzl, 2005; Samdal et al., 2016; Stea, Knutsen \& Torstveit, 2014; Stea \& Torstveit, 2014). I sin metastudie, hvor Rampersaud med kolleger (2005) ønsker å undersøke påstanden om at frokosten er det viktigste måltidet på dagen, finner de blant annet 
at inntak av frokost øker elevenes hukommelse, karakterer og oppmøte på skolen. I tillegg finner de at flere og flere elever hopper over frokosten jo eldre de blir, og at inntak av frokost avhenger av elevenes hjemmebakgrunn (sosioøkonomisk status).

En annen faktor som også kan virke inn, er søvn. Søvnmangel blant ungdom har vist seg å ha sammenheng med dårlig atferdsregulering og lave prestasjoner (Dewald, Meijer, Oort, Kerkhof \& Bõgels, 2010; Schmidt \& Van der Linden, 2015). Ifølge Schmidt og Van der Linden kan konsekvenser av dårlig atferdsregulering grunnet søvnmangel få konsekvenser som eksempelvis hyperaktivitet og aggresjon. Og, ifølge Dewald og kolleger, søvnmangel kan skyldes en kombinasjon av indre faktorer som pubertet og ytre faktorer som tidspunkt på dagen for skolestart. Nordgård Vik, Nilsen og Øverbys helt ferske norske studie (i trykk) kan bekrefte at mangel på søvn og frokost hadde en negativ sammenheng med prestasjoner $\mathrm{i}$ naturfag og matematikk. Analysene baserte seg på norske data fra TIMSS 2015 og TIMSS 2019 på 9. trinn, og viste også at andelen elever som møtte sultne og/eller trøtte på skolen, hadde økt i denne fireårsperioden.

For å gi en overordnet oppsummering av den teoretiske bakgrunnen for dette kapitlet viser tidligere forskning at lærernes kompetanse og undervisning har en positiv sammenheng med elevenes prestasjoner, mens lærernes undervisningskvalitet vil variere med elevsammensetningen (eller med begrensningen elevsammensetningen har for undervisningen) i en klasse. Blir det for mange elever i en klasse, som for eksempel mangler forkunnskaper, har atferdsproblemer og møter trøtte og sultne på skolen, kan dette gå ut over både undervisningskvaliteten og elevenes prestasjoner.

\subsection{METODE}

\subsubsection{Om data}

For å svare på forskningsspørsmålene i dette kapitlet benyttes data fra 9. trinn i TIMSS-undersøkelsene ${ }^{5}$ som ble gjennomført i 2015 og 2019. Mer spesifikt hentes data fra naturfaglærernes spørreskjema knyttet til deres kompetanse og undervisning. I tillegg benyttes den delen av elevenes spørreskjema som handler om hvordan de oppfatter lærernes undervisning og elevenes samlede prestasjon i naturfag. Alle spørreskjemaer benyttet i TIMSS-undersøkelsene kan lastes ned fra timss.no.

5 For mer informasjon om TIMSS-undersøkelsene se kapittel 1 i denne antologien eller timss.no. 


\subsubsection{Om utvalget}

I TIMSS 2015 og 2019 hadde elevenes naturfaglærere undervist i gjennomsnitt 1213 år (se almanakk for lærere, Fishbein, Foy \& Yin, 2021; Foy, 2017). På 9. trinn i TIMSS 2015 deltok 4697 elever og 224 naturfaglærere, mens det deltok 4575 elever og 240 naturfaglærere i 2019. I begge undersøkelsene deltok like mange jenter som gutter, og elevene var i gjennomsnitt 14,7 år da undersøkelsene ble gjennomført (se almanakk for elever, Fishbein et al., 2021; Foy, 2017).

\subsubsection{Variabler og konstrukter}

Selv om alle spørreskjemaer knyttet til TIMSS-undersøkelsen i utgangspunktet skal være så like som mulig fra gjennomføring til gjennomføring for å kunne følge med på trend, må de også oppdateres for å følge med på utviklingen i samfunnet, og det jobbes hele tiden med å forbedre validiteten og kvaliteten til de ulike variablene som er inkludert (Hooper, Mullis, Martin \& Fishbein, 2017). Dette fører noen ganger til at variabler tas ut og andre legges til. Da det i dette kapitlet handler om å undersøke endringer over tid, er det viktig at enkeltvariabler og samlevariabler er helt like slik at de kan sammenlignes. I det videre presenteres derfor variabler som er identiske på tvers av TIMSS 2015 og TIMSS 2019.

Til analysene i dette kapitlet, i tillegg til elevenes naturfagprestasjoner, tas det utgangspunkt i variabler som er knyttet til lærernes kompetanse, undervisning og hvilke faktorer lærerne opplever som hindringer for undervisningen. Som tidligere beskrevet i kapittel 8.2.1 deles lærernes kompetanse ofte inn i formelle kvalifikasjoner og profesjonskompetanse. Denne inndelingen benyttes også her selv om TIMSS ikke måler lærernes profesjonskompetanse direkte. Som indikatorer på profesjonskompetanse brukes lærernes rapportering av fagspesialisering og deres selvtillit knyttet til egen fagdidaktisk kunnskap.

Som et mål på lærernes formelle kvalifikasjoner benyttes spørsmålet om høyeste formelle utdanning. Her gis lærerne 7 alternativer som går fra ikke fullført videregående skole til doktorgrad.

Fagspesialisering defineres her som ett års fulltidsstudium (60 studiepoeng) eller mer. Lærerne som deltar i TIMSS, bes om å svare ja eller nei på om de har 60 studiepoeng eller mer i hvert av fagene biologi, fysikk, kjemi, geofag og naturfagdidaktikk.

Naturfaglærernes etter- og videreutdanningsaktivitet knyttes til sju ulike temaer, og lærerne blir spurt om de har deltatt på en eller flere EVU-aktiviteter med ett eller flere av de sju temaene i løpet av de siste to årene. Temaene er naturfaglige emner, naturfagdidaktikk (undervisningsmetoder), loreplan $i$ naturfag, 
bruk av IKT i naturfag, utvikling av elevenes kritiske tenkning eller utforskende ferdigheter, vurdering av naturfag og tilpasset opploring. Svaralternativene er ja eller nei, og lærerne kan krysse av for ja på alle temaer som er aktuelle. For å måle lærernes fagdidaktiske trygghet blir de spurt om å ta stilling til 10 forskjellige utsagn. Grad av trygghet angis på en firedelt skala fra «svært trygg» til «svært utrygg», og lærerne blir bedt om å tenke på selve undervisningssituasjonen og hvor trygge de føler seg til, for eksempel, å forklare naturfaglige begreper eller prinsipper via forsøk, gi flinke elever utfordringer, gjøre naturfag relevant for elevene og bruke utforskende metoder. For å se alle ti påstandene, se for eksempel i TIMSS 2019 Lærerspørreskjema naturfag, 9. $\operatorname{trinn}^{6}$ (spm. nr. 25).

På linje med tidligere forskning benyttes elevenes rapportering av lærernes undervisningskvalitet i denne undersøkelsen (se f.eks. Baier et al., 2018; Fauth, Decristan, Rieser, Klieme \& Büttner, 2014; Ferguson, 2012; Kyriakides et al., 2014; Wagner et al., 2016). Elevene blir bedt om å tenke på naturfagundervisningen de får, og ta stilling til hvor enige de er i følgende fem utsagn: Jeg vet hva loereren forventer av meg, Loreren er lett å forstå, Loereren har klare svar på spørsmålene mine, Lœreren er flink til å forklare naturfag og Lœreren gjør mange forskjellige ting for å hjelpe oss å loere. Grad av enighet angis på en firedelt skala fra «svært enig»til «svært uenig». Påstandene i dette målet hører inn under det aspektet av undervisningskvalitet som i kapittel 8.2.2 ble beskrevet som støttende undervisningspraksis. Aspektet kognitiv aktivering i naturfagundervisningen ble i TIMSS 2019 lagt til som et nasjonalt tillegg for første gang og kan derfor ikke inkluderes i disse analysene.

For å undersøke begrensninger for naturfagundervisningen i sin klasse blir lærerne bedt om å forholde seg til fem påstander. Påstandene handler om i hvor stor grad undervisningen begrenses av elever som mangler kunnskaper eller ferdigheter, ikke har et sunt kosthold, ikke fär nok søvn, forstyrrer undervisningen og er uinteressert $i$ undervisningen. Grad av begrensning angis på en tredelt skala fra «ikke i det hele tatt» via «litt» til «mye».

Mens lærernes utdanningsnivå er en enkeltvariabel, er de fire neste (fagspesialisering, fagdidaktisk trygghet, undervisningskvalitet og begrensninger for undervisningen) latente variabler hvor alle påstandene inkluderes (se f.eks. Hox, 2010).

Elevenes samlede naturfagprestasjon er, både i TIMSS 2015 og 2019, målt med 220 oppgaver som er tilpasset rammeverket for naturfag i TIMSS. Rammeverket definerer hvilke kunnskaper og ferdigheter elevene skal testes i (se f.eks. Mullis \& Martin, 2017). Oppgavene blir fordelt på 14 mindre oppgavesett. Hver elev får ett

6 Hele lærerspørreskjemaet i naturfag på 9. trinn kan lastes ned fra timss.no. 
oppgavesett som inneholder omtrent 30 oppgaver, og 45 minutter til å løse oppgavene. Omtrent halvparten av oppgavene i hvert sett består av flervalgsoppgaver hvor ett av fire svaralternativ er korrekt, den andre halvparten består av oppgaver hvor elevene må formulere svaret selv (åpne oppgaver). For mer om hvordan TIMSS-undersøkelsen dekker alle emnene som er inkludert i rammeverket for naturfag (og matematikk), se for eksempel Nilsen og Kaarstein (2016) og Mullis og Martin (2017).

\subsubsection{Analyser}

Et ideelt forskningsdesign for å se på utvikling over tid for en variabel er et såkalt longitudinelt design hvor de samme personene (populasjonen) deltar i undersøkelsen gjentatte ganger over tid (Menard, 2008). Men ifølge Menards fire mulige alternativer for longitudinell design passer TIMSS-undersøkelsen, som gjennomføres hvert fjerde år med representative utvalg av elever på 5. og 9. trinn, inn i det som han kaller «repeated cross-sectional design» (gjentatt tverrsnittsmåling) for longitudinell forskning. I tillegg settes TIMSS-resultatene på den samme skalaen hver gang slik at resultatene fra én undersøkelse kan sammenlignes med resultatene i de foregående for å oppdage trender (for mer om skalering, se Foy, Fishbein, von Davier \& Yin, 2020). En slikt trend- og repeterende tverrsnittsmåling gjør det mulig å trekke mer robuste slutninger om endringer for populasjonen av elever på et gitt trinn over tid, enn slutninger trukket på grunnlag av tverrsnittsdata fra ett undersøkelsestidspunkt (Gustafsson \& Nilsen, i trykk; Kaplan \& Jude, i trykk).

For å undersøke endringer fra én gjennomføring til den neste må datasettene for de to gjennomføringene slås sammen til ett datasett (Nilsen \& Gustafsson, 2014). I det nye datasettet inkluderes en hjelpevariabel som angir hvilke resultater som kommer fra 2015, og hvilke som kommer fra 2019. Denne variabelen benyttes videre i analysen som et mål på tid mellom 2015 og 2019. Variabelen Tid settes til 0 i 2015 og 1 i 2019.

Siden det er kjent at elevenes naturfagprestasjoner på 9. trinn er statistisk signifikant lavere i TIMSS 2019 enn de var i TIMSS 2015 (Kaarstein et al., 2020; Mullis, Martin, Foy, Kelly \& Fishbein, 2020), kan en første antagelse være at en endring i variabelen Tid har en negativ effekt på endringen i prestasjonene, som illustrert i figur 8.1.

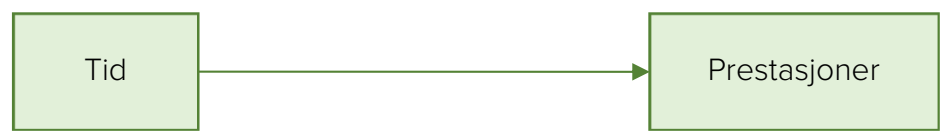

Figur 8.1 Effekt av tid på prestasjoner. 
Hypotesen som legger grunnlaget for forskningsspørsmålet i dette kapitlet er imidlertid at endringene i elevenes naturfagprestasjoner kanskje kan relateres til endringer i variabler knyttet til lærerne, deres undervisning og opplevde hindringer for undervisningen i tillegg til, eller istedenfor, tiden. Derfor undersøkes det om hver av de ulike lærervariablene omtalt i 8.3.3 kan mediere effekten av tid på prestasjoner, altså om lærervariablene kan bidra til å forklare endringen i naturfagprestasjoner på 9. trinn. Se konseptuell analysemodell for mediering i figur 8.2.

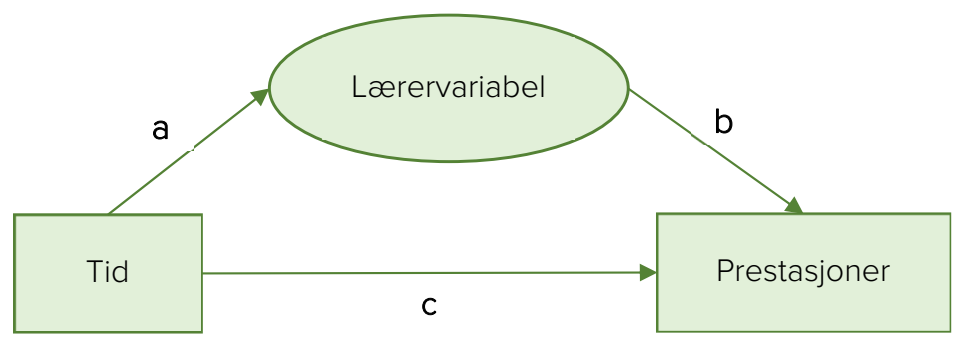

Figur 8.2 Konseptuell analysemodell: endring i lærervariabel medierer tiden.

I figur 8.2 står a for effekten av endring i tid på endring i lærervariabel, eller sagt på en annen måte, a viser om det har vært en endring i lærervariabelen fra 2015 til 2019 , mens $\mathbf{b}$ angir effekten av selve lærervariabelen på elevenes prestasjoner. Bokstaven $\mathbf{c}$ angir endringer i prestasjoner fra 2015 til 2019, og omtales ofte som den direkte effekten, mens produktet av $\mathbf{a}$ og $\mathbf{b}$ utgjør den indirekte effekten. Den totale effekten er summen av direkte og indirekte effekt. Dersom den indirekte effekten er signifikant, betyr det at medieringsvariabelen (f.eks. lærerens utdanningsnivå) kan bidra til å forklare enten deler av eller hele endringen i prestasjoner (delvis eller full mediering, se f.eks. Mathieu \& Taylor, 2006).

Det benyttes 2-nivå (elever, klasser) strukturell ligningsmodellering (SEM) og konfirmatorisk faktoranalyse (CFA) for å undersøke validitet og reliabilitet (Hox, 2010). Det ble først gjennomført CFA for de latente variablene og deretter SEM. Den hierarkiske oppbyggingen av data i TIMSS ivaretas av TYPE $=$ COMPLEX. Elevene grupperes i klasser siden det antas at lærervariablene fører til større forskjeller mellom klasser enn mellom skoler. Figur 8.2 viser derfor medieringsmodellen på klassenivå.

Til analysene benyttes programmet Mplus, versjon 8 (Muthén \& Muthén, 19982017). Programmet gir regresjonskoeffisienter og hvor godt analysemodellen (i figur 8.2) er tilpasset dataene (Hox, 2010; Hox \& Roberts, 2011). I tillegg beregnes direkte og indirekte effekter av mediering ved å benytte MODEL INDIRECT i 
Mplus. For å ta høyde for manglende verdier for variablene benyttes MLR (robust maximum likelihood, se f.eks. Puthenpura \& Sinha, 1986).

\subsection{RESULTATER}

I dette kapitlet gis en kort presentasjon av resultatene.

Alle de undersøkte variablene, bortsett fra lærernes fagspesialisering og EVUaktivitet, hadde signifikante endringer fra TIMSS 2015 til TIMSS 2019 og ble dermed inkludert i de videre medieringsanalysene. Analysemodellen passet bra for de tre latente variablene som ble benyttet videre i analysen ifølge anbefalinger for god modelltilpasning gitt i Hox og Roberts (2011). RMSEA var under 0,025, og CFI/ TLI var over 0,95 for alle de latente variablene. Videre lå alle faktorladningene stort sett rundt 0,7-0,8 (laveste var på 0,5), hvilket innebærer at alle påstandene som er inkludert i den latente variabelen, måler det samme underliggende begrepet.

I tabell 8.1 vises resultatene av analysene, og det oppgis både ustandardiserte og standardiserte regresjonskoeffisienter - standardiserte i parentes. I tabellen refererer bokstavene a, b og c til figur 8.2.

Tabell 8.1 Regresjonskoeffisienter fra medieringsanalysen. Standardiserte koeffisienter i parentes

\begin{tabular}{|l|c|c|c|c|}
\hline Variabel & $\begin{array}{c}\text { Effekt av tid på } \\
\text { variabel } \\
\text { a }\end{array}$ & $\begin{array}{c}\text { Effekt av varia- } \\
\text { bel på prestasjon } \\
\text { b }\end{array}$ & $\begin{array}{c}\text { Effekt av tid på } \\
\text { prestasjon } \\
\text { c }\end{array}$ & $\begin{array}{c}\text { Indirekte } \\
\text { effekt }\end{array}$ \\
\hline $\begin{array}{l}\text { Høyeste formelle utdan- } \\
\text { ning }\end{array}$ & $0,29(0,25)^{\star *}$ & $10,89(0,07)^{\star}$ & $-17,14(-0,10)^{\star *}$ & $3,11(0,02)^{\star}$ \\
\hline Fagdidaktisk trygghet & $0,30(0,37)^{\star *}$ & $11,67(0,06)^{\star}$ & $-17,50(-0,10)^{\star *}$ & $3,47(0,02)^{\star}$ \\
\hline Undervisningskvalitet & $0,07(0,07)^{\star}$ & $27,17(0,15)^{\star *}$ & $-15,95(-0,09)^{\star *}$ & $1,92(0,01)^{\star}$ \\
\hline $\begin{array}{l}\text { Begrensninger for under- } \\
\text { visningen }\end{array}$ & $-0,13(-0,20)^{\star}$ & $47,20(0,17)^{\star *}$ & $-8,01(-0,05)^{\star}$ & $-6,02(-0,04)^{\star}$ \\
\hline
\end{tabular}

* Signifikansnivå $p<0,05 .{ }^{* *}$ Signifikansnivå $p<0,001$.

Den totale effekten er summen av effekt av tid på prestasjoner (c i tabell 8.1) og indirekte effekt, og dette stemmer godt med den faktiske/reelle nedgangen i elevenes naturfagprestasjoner på 13-14 poeng ${ }^{7}$.

7 Elevenes samlede naturfagprestasjon på 9. trinn i TIMSS 2015 var på $509(2,8)$ poeng. I 2019 var den på 495 (3,1) poeng, standardfeil i parentes (Mullis et al., 2020). Om det er 13 eller 14 poeng, kommer an på avrundingen av resultatene. 
Av tabellens andre kolonne fremgår det at det i 2019 var signifikant flere lærere med høyere formell utdanning, lærerne rapporterte om høyere grad av fagdidaktisk trygghet, og elevenes vurdering av lærernes undervisningskvalitet var høyere enn i 2015. Variabelen «Begrensninger for undervisningen» har en negativ endring, hvilket innebærer at lærerne rapporterer at de opplever en høyere grad av begrensninger for undervisningen i 2019 enn de rapporterte i 2015.

Videre viser den tredje kolonnen i tabell 8.1 at alle variablene har en positiv sammenheng med prestasjoner. Det betyr at for hver enhet oppover på skalaen til variabelen, øker elevenes prestasjoner med det antall poeng som står i den tredje kolonnen. For eksempel, når lærernes fagdidaktiske trygghet går opp med 1 enhet (f.eks. fra litt trygg til svært trygg), øker elevenes prestasjoner med omtrent 11 poeng. Ut fra beregninger gjort for de norske resultatene i TIMSS 2015 tilsvarer en slik økning omtrent et halvt skoleår (Bergem et al., 2016; Kaarstein et al., 2020).

Når den indirekte effekten blir signifikant, slik den gjør for alle variablene som er inkludert i tabell 8.1 (se siste kolonne), betyr det at variabelen medierer tiden, eller er med på å forklare endringene i prestasjoner (i tillegg til at tiden har gått, som er den direkte effekten, c). Den ustandardiserte verdien angir hvor mange poeng av endringen i prestasjoner variabelen kan forklare. Eksempelvis bidrar «Begrensninger for undervisningen» til å forklare omtrent 6 poeng av den registrerte nedgangen i naturfagprestasjoner, mens den direkte effekten nå «bare» forklarer 8. Den totale effekten av begrensninger for undervisningen på prestasjoner blir da $-6-8=-14$ (poeng), som er som forventet (at den ikke blir -13 poeng slik som rapportert $\mathrm{i}$ både norsk og internasjonal rapport, skyldes avrundinger i utregningene). Dersom den indre effekten er positiv, kan det sies at variabelen er med på å motvirke nedgangen.

\subsection{DISKUSJON}

\subsubsection{Kort oppsummering av funn}

Alle lærervariablene som er inkludert i dette kapitlet, bortsett fra lærernes fagspesialisering og EVU-aktivitet, hadde signifikante endringer fra TIMSS 2015 til TIMSS 2019. Lærernes generelle utdanningsnivå, deres fagdidaktisk trygghet og undervisningskvalitet økte, mens begrensninger for undervisningen har endret seg til det verre. Videre hadde alle disse variablene, også begrensninger for undervisningen, en positiv sammenheng med elevenes prestasjoner (få begrensninger henger sammen med gode prestasjoner), og alle variablene medierte effekten av tiden på elevenes naturfagprestasjoner. 
At lærernes utdanningsnivå, fagdidaktiske trygghet og undervisningskvalitet medierte tiden i positiv retning, kan tolkes som om de har hatt en motvirkende effekt på elevenes nedgang. Altså, uten en økning i disse variablene kunne elevenes nedgang muligens vært større. Begrensninger for undervisningen medierte tiden i negativ retning, hvilket betyr at begrensningene ser ut til å ha bidratt til, eller kan forklare, deler av nedgangen.

\subsubsection{Diskusjon av funn i lys av teori}

Ut fra analysene i dette kapitlet kan det se ut som om satsingen på å øke lærernes kompetanse og de innførte kravene knyttet til undervisning har gitt resultater. Det er flere elever som undervises av lærere med høyere utdanning i TIMSS 2019 enn det var i TIMSS 2015. Dette stemmer godt med kartleggingen av lærernes kompetanse i grunnskolen for skoleåret 2018/2019, gjennomført av Statistisk sentralbyrå (SSB: Perlic, 2019). I den samme SSB-rapporten antydes det også at den store satsingen på realfagene har ført til en høyere andel lærere med studiepoeng i matematikk og naturfag. Dette er derimot ikke synlig i TIMSS-dataene for naturfaglærernes del (Kaarstein et al., 2020). At det ikke er synlig i TIMSS-data, kan henge sammen med hvordan fagspesialisering defineres i undersøkelsen (minimum ett års fulltidsstudium), og det kan ha sammenheng med en av begrensningene for denne studien, nemlig at den ikke har et representativt utvalg lærere (for mer om begrensninger, se kap. 8.5.3).

Ifølge tidligere forskning henger lærernes profesjonsutvikling i form av etter- og videreutdanningsaktivitet sammen med både høyere fagdidaktisk trygghet og økt undervisningskvalitet (Blömeke, Olsen \& Suhl, 2016; Fauth et al., 2019; Gustafsson \& Nilsen, 2016). I datagrunnlaget for dette kapitlet var det ingen endring i naturfaglærernes etter- og videreutdanningsaktivitet fra TIMSS 2015 til 2019 som kunne ha vært med på å forklare hvorfor det, i det samme datagrunnlaget, har vært en økning i lærernes fagdidaktiske trygghet og undervisningskvalitet. Nå er det riktignok elevene og ikke lærerne som rapporterer om undervisningskvalitet, men det er en anerkjent måte å måle undervisningskvalitet på (Fauth et al., 2014; Kyriakides et al., 2014), og variablene ble målt på eksakt samme måte med fire års mellomrom. Selvsagt kan det også være andre faktorer som har bidratt til en økning i fagdidaktisk trygghet og undervisningskvalitet, men spørsmålet om hvilke faktorer og hvorfor det har økt, må sendes videre til andre.

Når det gjelder sammenhengen mellom de inkluderte variablene i dette kapitlet og elevenes naturfagprestasjoner, peker resultatene i samme retning som tidligere funn både internasjonalt og nasjonalt - lærernes kompetanse og undervisnings- 
kvalitet har en sammenheng med elevenes prestasjoner. Med søkelys på naturfaglærernes kompetanse i betydningen fagdidaktisk kunnskap, fagdidaktisk trygghet og entusiasme fant Fauth og kolleger (2019) en positiv sammenheng mellom naturfaglærernes kompetanse og elevenes interesse for faget. I tillegg viste deres resultater at fagdidaktisk trygghet hos lærerne var relatert til elevenes prestasjoner. I tidligere analyser av norske TIMSS-data på 9. trinn fant Kaarstein, Nilsen og Blömeke (2016) at naturfaglærernes faglige og fagdidaktiske trygghet hadde en sammenheng med deres undervisningskvalitet, og videre at undervisningskvalitet var relatert til elevenes naturfagprestasjoner. I studien fra 2016 ble undervisningskvalitet rapportert av lærerne og inkluderte både aspektet støttende loerer og kognitiv utfordring.

Men selv med en kompetent lærer kan det finnes ulike faktorer som hindrer god undervisning (Abebe \& Hailemariam, 2007; Oliver et al., 2011; Wang \& Degol, 2014). Dette kapitlet har sett spesielt på hvordan lærerne har oppfattet at undervisningen deres har blitt begrenset av elevenes mangel på søvn, sunt kosthold, kunnskaper eller ferdigheter, og $\mathrm{i}$ hvor stor grad elevene forstyrrer eller er uinteresserte $\mathrm{i}$ undervisningen. Som forventet ut fra tidligere forskning viste resultatene i dette kapitlet at det er en positiv sammenheng mellom fravoer av begrensninger og prestasjoner (ibid.). Og videre, ut fra resultatene listet opp i tabell $8.1 \mathrm{er}$ det nettopp denne variabelen som har sterkest sammenheng med elevenes prestasjoner relativt til de andre variablene, men det er også denne variabelen som har hatt negativ endring over tid og kan sies å ha en sammenheng med nedgangen i prestasjoner.

At variabelen har endret seg med tanke på søvn og kosthold, støttes blant annet av Hysing og kolleger (2013), som fant at norske tenåringer sover mindre nå enn før, og ifølge undersøkelsen «Helsevaner blant skoleelever. En WHO-undersøkelse i flere land» er det mange som dropper frokost, og andelen som dropper frokost, blir høyere jo eldre elevene blir (Samdal et al., 2016). Det å forstyrre og/eller være uinteressert i undervisningen kan ses på som problematferd (se f.eks. Oliver et al., 2011; Wang \& Degol, 2014), men ifølge Sørlie og Ogden (2014) foreligger det lite norsk forskning på utviklingen av elevers atferd over tid. I deres studie fant de at norske lærere rapporterte om mindre problematferd i 2008 enn i 1998, men dette kan ha endret seg. Følgelig trengs det oppdatert forskning på dette punktet.

Videre kan det å forstyrre og/eller være uinteressert i undervisning være nært knyttet til det å mangle ferdigheter, kunnskap og forståelse (her: i og for naturfag). Å svare på hvorfor elevene eventuelt mangler ferdigheter, kunnskaper og/eller forståelse, krever videre undersøkelser - har det for eksempel skjedd endringer i barneskolen eller ungdomskolen for 2019-kohorten sammenlignet med 2015-kohorten som kan forklare dette? 


\subsubsection{Svakheter ved studien}

En av svakhetene ved denne studien er knyttet til designet. I TIMSS-undersøkelsen samles det i utgangspunktet inn tverrsnittsdata som ikke gir grunnlag for å trekke kausale slutninger. Det ideelle hadde vært å enten benytte et longitudinelt design som fulgte de samme elevene over tid (svært krevende), eller gjennomføre et randomisert, kontrollert eksperiment. Men siden TIMSS også er en trendundersøkelse, fører det likevel til at det er mulig å trekke mer robuste slutninger ved bruk av avanserte kausale metoder når data fra påfølgende undersøkelser benyttes for å se på endringer over tid (Gustafsson, 2013; Gustafsson \& Nilsen, i trykk).

Lærerne som deltar i TIMSS-undersøkelsen, utgjør ikke et representativt utvalg, hvilket innebærer at resultatene ikke uten videre kan generaliseres. Grunnen til at resultatene likevel omtales i mer generelle vendinger, er at dette er de lærerne som underviser et representativt utvalg elever på 9. trinn i Norge.

Videre benyttes selvrapporterte data fra lærere og elever i analysene. Det er omdiskutert hvor objektive disse rapportene er (Kunter \& Baumert, 2006). Selv om omfattende (og svært ressurskrevende) observasjoner i representative klasserom kunne gitt mer objektive data og mer omfattende informasjon, viser for eksempel Kyriakides med kolleger (2014) og Wagner med kolleger (2016) at elevenes rapporteringer om lærerens undervisning er like valide som observasjoner.

Det vil alltid være knyttet usikkerhet til hvor godt variablene representerer det som ønskes målt (Kleven, 2008). Selv om det i kapittel 8.2.2 ble introdusert tre aspekter av undervisningskvalitet, vil disse bare kunne gi et lite innblikk i en svært sammensatt virkelighet. Hvilket vil si at det ene aspektet som inngikk i analysene (støttende lærer), ikke dekker undervisningskvalitet i sin helhet. I tillegg kan det være at de fem utsagnene som inngår i variabelen, også underrepresenterer aspektet støttende loerer.

Når det gjelder begrensninger for undervisningen, er det spesielt to forhold som bør nevnes. Det ene er at denne variabelen ikke måler den faktiske elevsammensetningen i klassene, men lærernes oppfatning av hvordan kombinasjonen av elevens mangler, begrenser undervisningen. Det andre er, på samme måte som for undervisningskvalitet, knyttet til underrepresentasjon av variabelen. Eksempelvis inkluderer den ikke elever som har utfordringer knyttet til språk.

På grunn av kompleksiteten i en undervisningssituasjon vil alle variablene undersøkt i dette kapitlet, i større eller mindre grad, overlappe med eller være avhengige av hverandre. Derfor har vi modellert variablene hver for seg fremfor å inkludere alle i en modell. Dette betyr at ingen av verdiene (verken de ustandardiserte eller standardiserte) som vises i tabell 8.1, kan benyttes som eksakte mål, men de kan benyttes som indikasjon på at variablene har noe å si for elevenes prestasjo- 
ner, om de bidrar eller motvirker, og de kan si noe om (relativ) styrke. Begrensninger for undervisningen bidrar «mer» enn undervisningskvalitet motvirker (hhv. 6,02 og 1,92 poeng, se tabell 8.1).

For å fremheve kompleksiteten i en undervisningssituasjon kan den undersøkte endringen $i$ elevprestasjoner dessuten ha sammenheng med endringer i variabler eller karakteristika som er knyttet til elevene, som for eksempel språk og kjønn (se kapittel 7 i denne antologien), faglig motivasjon og selvtillit, og/eller endringer i deres skolemiljø som eksempelvis mobbing, skoletilhørighet og de foresattes engasjement/støtte (se kapittel 6 i denne antologien) i tillegg til variabler knyttet til lærerne, undervisningskvalitet og elevsammensetning som dette kapitlet har fokusert på.

\subsubsection{Avsluttende kommentarer}

Dette kapitlet har sett på om nedgangen i elevenes naturfagprestasjoner fra TIMSS 2015 til TIMSS 2019 kan knyttes til endringer i karakteristika ved lærerne, deres undervisning og hvor store begrensninger for undervisningen elevsammensetningen har. Av de inkluderte variablene hadde alle en endring fra 2015 til 2019, bortsett fra lærernes fagspesialisering og etter- og videreutdanningsaktivitet. Dette førte til at de to sistnevnte ikke ble inkludert i medieringsanalysen.

Den eneste av variablene med negativ endring var begrensninger for undervisningen, og resultatet av analysene antyder at denne delvis også er med på å forklare nedgangen i elevenes naturfagprestasjoner. Hvorfor det har vært en nedgang og hvilke tiltak som kan settes inn for å hindre videre forverring av elevenes fysiske og psykiske helse, mangel på interesse for undervisningen og forkunnskaper, krever videre forskning.

Når det gjelder lærernes kompetanse og undervisningskvalitet, hadde alle variablene en positiv økning fra 2015 til 2019. Lærernes (generelle) utdanningsnivå er høyere, de har høyere fagdidaktisk trygghet, og elevene melder om økt undervisningskvalitet i form av opplevd støtte fra lærerne. I tillegg, når de samme variablene også viser seg å kunne bidra til å motvirke nedgang i elevenes prestasjoner til tross for at lærerne rapporterer om høyere grad av begrensninger for undervisningen, gir det ytterligere støtte til det innledende sitatet:

Lærerne er skolens viktigste ressurs. Nøkkelen til å løfte kunnskapen blant elevene er å satse på lærernes kompetanse. 


\section{REFERANSER}

Abebe, S. \& Hailemariam, A. (2007). The Challenges of Managing Student Behavior Problems in the Classroom. Online submission.

Abell, S.K. (2008). Twenty Years Later: Does pedagogical content knowledge remain a useful idea? International Journal of Science Education, 30(10), 1405-1416. Hentet fra http://www.informaworld.com/smpp/content $\sim$ content $=\mathrm{a} 795251439 \sim \mathrm{db}=$ all

Baier, F., Decker, A.-T., Voss, T., Kleickmann, T., Klusmann, U. \& Kunter, M. (2018). What makes a good teacher? The relative importance of mathematics teachers' cognitive ability, personality, knowledge, beliefs, and motivation for instructional quality. British Journal of Educational Psychology, 89(4), 767-786. https://doi.org/10.1111/bjep.12256

Baumert, J., Kunter, M., Blum, W., Brunner, M., Voss, T., Jordan, A., Klusmann, U., Krauss, S., Neubrand, M. \& Tsai, Y.-M. (2010). Teachers' Mathematical Knowledge, Cognitive Activation in the Classroom, and Student Progress. American Educational Research Journal, 47(1), 133 180. Hentet fra http://aer.sagepub.com/content/47/1/133.abstract

Bergem, O.K., Kaarstein, H. \& Nilsen, T. (Red.). (2016). Vi kan lykkes i realfag. Resultater og analyser fra TIMSS 2015. Universitetsforlaget.

Blömeke, S. (2017). Modelling teachers' professional competence as a multi-dimensional construct. I S. Guerriero (Red.), Pedagogical Knowledge and the Changing Nature of the Teaching Profession (s. 119-135). OECD Publishing.

Blömeke, S., Busse, A., Kaiser, G., König, J. \& Suhl, U. (2016). The relation between content-specific and general teacher knowledge and skills. Teaching and Teacher Education, 56, 35-46. https://doi.org/10.1016/j.tate.2016.02.003

Blömeke, S., Gustafsson, J.-E. \& Shavelson, R. (2015). Beyond dichotomies: Competence viewed as a continuum. Zeitschrift für Psychologie, 223(1), 3-13. http://dx.doi.org/10.1027/2151-2604/ a000194

Blömeke, S. \& Olsen, R.V. (2019). Consistency of results regarding teacher effects across subjects, school levels, outcomes and countries. Teaching \& Teacher Education, 77, 170-182.

https://doi.org/10.1016/j.tate.2018.09.018

Blömeke, S., Olsen, R.V. \& Suhl, U. (2016). Relation of Student Achievement to the Quality of Their Teachers and Instructional Quality. I T. Nilsen \& J.-E. Gustafsson (Red.), Teacher Quality, Instructional Quality and Student Outcomes. Relationships Across Countries, Cohorts and Time (vol. 2, s. 21-50). Springer Open.

Bolyard, J.J. \& Moyer-Packenham, P.S. (2008). A Review of the Literature on Mathematics and Science Teacher Quality. Peabody Journal of Education, 83(4), 509-535. https:/doi.org/ 10.1080/01619560802414890

Bryan, L.A. (2012). Research on Science Teacher Beliefs. I B.J. Fraser, K. Tobin \& C.J. McRobbie (Red.), Second International Handbook of Science Education (s. 477-495). Springer Netherlands.

Burić, I. \& Kim, L.E. (2020). Teacher self-efficacy, instructional quality, and student motivational beliefs: An analysis using multilevel structural equation modeling. Learning and Instruction, 66, 101302. doi: https://doi.org/10.1016/j.learninstruc.2019.101302 
Burrows, T., Goldman, S., Pursey, K. \& Lim, R. (2017). Is there an association between dietary intake and academic achievement: a systematic review. Journal of Human Nutrition and Dietetics, 30(2), 117-140. https://doi.org/10.1111/jhn.12407

Cakiroglu, J., Capa-Aydin, Y. \& Hoy, A.W. (2012). Science Teaching Efficacy Beliefs. I B.J. Fraser, K. Tobin \& C.J. McRobbie (Red.), Second International Handbook of Science Education (s. 449461). Springer Netherlands.

Cohen, J. \& Grossman, P. (2016). Respecting complexity in measures of teaching: Keeping students and schools in focus. Teaching and Teacher Education, 55, 308-317. https://doi.org/ 10.1016/j.tate.2016.01.017

Creemers, B. \& Kyriakides, L. (2010). School Factors Explaining Achievement on Cognitive and Affective Outcomes: Establishing a Dynamic Model of Educational Effectiveness. Scandinavian Journal of Educational Research, 54(3), 263-294. https://doi.org/10.1080/00313831003764529

Darling-Hammond, L. (2000). Teacher Quality and Student Achievement: A Review of State Policy Evidence. Education Policy Analysis Archives, 8(1). https://doi.org/10.14507/epaa.v8n1.2000

Dewald, J.F., Meijer, A.M., Oort, F.J., Kerkhof, G.A. \& Bõgels, S.M. (2010). The influence of sleep quality, sleep duration and sleepiness on school performance in children and adolescents: A meta-analytic review. Sleep Medicine Reviews, 14(3), 179-189.

Fauth, B., Decristan, J., Decker, A.-T., Büttner, G., Hardy, I., Klieme, E. \& Kunter, M. (2019). The effects of teacher competence on student outcomes in elementary science education: The mediating role of teaching quality. Teaching and Teacher Education, 86, 102882.

https://doi.org/10.1016/j.tate.2019.102882

Fauth, B., Decristan, J., Rieser, S., Klieme, E. \& Büttner, G. (2014). Student ratings of teaching quality in primary school: Dimensions and prediction of student outcomes. Learning and Instruction, 29, 1-9. http://dx.doi.org/10.1016/j.learninstruc.2013.07.001

Ferguson, R.F. (2012). Can Student Surveys Measure Teaching Quality? Phi Delta Kappan, 94(3), 24-28. https://doi.org/10.1177/003172171209400306

Ferguson, R.F. \& Danielson, C. (2015). How Framework for Teaching and Tripod 7Cs Evidence Distinguish Key Components of Effective Teaching. I Designing Teacher Evaluation Systems (s. 98-143).

Fishbein, B., Foy, P. \& Yin, L. (2021). TIMSS 2019 User Guide for the International Database. Hentet fra https://timssandpirls.bc.edu/timss2019/international-database/

Foy, P. (2017). TIMSS 2015 User Guide for the International Database. Hentet fra https://timssandpirls.bc.edu/timss2015/international-database/

Foy, P., Fishbein, B., von Davier, M. \& Yin, L. (2020). Implementing the TIMSS 2019 scaling methodology. I M.O. Martin, M. von Davier \& I.V.S. Mullis (Red.), Methods and Procedures: TIMSS 2019 Technical Report. Hentet fra Boston College, TIMSS \&PIRLS International Study Center website: https://timssandpirls.bc.edu/timss2019/methods/chapter-12.html

Freiberg, J. (2013). Classroom Management and Student Achievement. I J. Hattie \& E.M. Anderman (Red.), International guide to student achievement (s. 228-230). Routledge.

Goe, L. (2007). The Link Between Teacher Quality and Student Outcomes: A Research Synthesis. Hentet fra: http://secc.sedl.org/orc/resources/LinkBetweenTQandStudentOutcomes.pdf Grønmo, L.S. \& Onstad, T. (2009). Tegn til bedring: norske elevers prestasjoner i matematikk og naturfag i TIMSS 2007. Unipub. 
Grønmo, L. S., Onstad, T., Nilsen, T., Hole, A., Aslaksen, H. \& Borge, I.C. (2012). Framgang, men langt fram: norske elevers prestasjoner i matematikk og naturfag i TIMSS 2011. Akademika forlag.

Gustafsson, J.-E. (2013). Causal inference in educational effectiveness research: a comparison of three methods to investigate effects of homework on student achievement. School Effectiveness and School Improvement, 24(3), 275-295. https://doi.org/10.1080/09243453.2013.806334

Gustafsson, J.-E. \& Nilsen, T. (2016). The Impact of School Climate and Teacher Quality on Mathematics Achievement: A Difference-in-Differences Approach. I T. Nilsen \& J.-E. Gustafsson (Red.), Teacher Quality, Instructional Quality and Student Outcomes. Relationships Across Countries, Cohorts and Time (vol. 4, s. 81-96). Springer Open.

Gustafsson, J.-E. \& Nilsen, T. (i trykk). Methods of causal analysis with ILSA data. I T. Nilsen, A.S. Stancel-Piątak \& J.E. Gustafsson (Red.), International Handbook of Comparative LargeScale Studies in Education. Springer.

Hattie, J. (2012). Visible learning for teachers : maximizing impact on learning. London: Routledge.

Hiebert, J. \& Grouws, D.A. (2007). The effects of classroom mathematics teaching on students' learning. I F. Lester (Red.), Second handbook of research on mathematics teaching and learning (s. 371-404). Information Age Publishing.

Hill, H.C., Rowan, B. \& Ball, D.L. (2005). Effects of Teachers' Mathematical Knowledge for Teaching on Student Achievement. American Educational Research Journal, 42(2), 371-406. https://doi.org/10.3102/00028312042002371

Hooper, M., Mullis, I.V.S., Martin, M.O. \& Fishbein, B. (2017). TIMSS 2019 Context Questionnaire Framework. I I.V.S. Mullis \& M.O. Martin (Red.), TIMSS 2019 Assessment Frameworks (s. 59-79). Chestnut Hill, MA: TIMSS \& PIRLS International Study Center, Boston College.

Hox, J.J. (2010). Multilevel Analysis. Techniques and Applications (2. utg.). Routledge.

Hox, J.J. \& Roberts, J.K. (2011). Handbook of advanced multilevel analysis. Routledge.

Hysing, M., Pallesen, S., Stormark, K.M., Lundervold, A.J. \& Sivertsen, B. (2013). Sleep patterns and insomnia among adolescents: a population-based study. J Sleep Res, 22(5), 549-556. https://doi.org/10.1111/jsr.12055

Jensen, F., Pettersen, A., Frønes, T.S., Kjærnsli, M., Rohatgi, A., Eriksen, A. \& Narvus, E.K. (2019). PISA 2018. Norske elevers kompetanse i lesing, matematikk og naturfag. Unversitetsforlaget.

Kaplan, D. \& Jude, N. (i trykk). Trendanalysis with international large-scale assessments: Past practice and future directions. In T. Nilsen, A.S. Stancel-Piątak \& J.E. Gustafsson (Red.), International Handbook of Comparative Large-Scale Studies in Education. Springer.

Kleven, T.A. (2008). Validity and validation in qualitative and quantitative research. Nordic Studies in Education, 3, 219-233. http://www.idunn.no/ts/np/2008/03/

validity_and_validation_in_qualitative_and_quantitative_research

Klieme, E., Pauli, C. \& Reusser, K. (2009). The Pythagoras Study: Investigating Effects of Teaching and Learning in Swiss and German Mathematics Classrooms. I J. Tomáš \& T. Seidel (Red.), The Power of Video Studies in Investigating Teaching and Learning in the Classroom (s. 137-160). Waxmann Verlag. 
Klingebiel, F. \& Klieme, E. (2016). Teacher Qualifications and Professional Knowledge I S. Kuger, E. Klieme, N. Jude \& D. Kaplan (Red.), Assessing Contexts of Learning. Methodology of Educational Measurement and Assessment. Springer.

Kuger, S., Klieme, E., Jude, N. \& Kaplan, D. (Red.). (2016). Assessing Contexts of Learning. An International Perspective. Springer.

Kunnskapsdepartementet. (2011). Meld. St. 22 (2010-2011) Motivasjon - Mestring - Muligheter. Ungdomstrinnet. Kunnskapsdepartementet.

Kunnskapsdepartementet. (2014). Lœrerløftet. På lag for kunnskapsskolen. Oslo: Kunnskapsdepartementet Hentet fra https://www.regjeringen.no/no/dokumenter/Larerloftet/id2001933/

Kunnskapsdepartementet. (2015). Tett på realfag. Nasjonal strategi for realfag $i$ barnehagen og grunnopploringen (2015-2019). Kunnskapsdepartementet. Hentet fra https://www.regjeringen.no/no/dokumenter/tett-pa-realfag/id2435042/

Kunter, M. \& Baumert, J. (2006). Who is the expert? Construct and criteria validity of student and teacher ratings of instruction. Learning Environments Research, 9(3), 231-251. https://doi.org/10.1007/s10984-006-9015-7

Kunter, M., Baumert, J., Blum, W., Klusmann, U., Krauss, S. \& Neubrand, M. (Red.). (2013). Cognitive Activation in the Mathematics Classroom and Professional Competence of Teachers. Results from the COACTIV Project. Springer.

Kunter, M., Klusmann, U., Baumert, J., Richter, D., Voss, T. \& Hachfeld, A. (2013). Professional competence of teachers: Effects on instructional quality and student development. Journal of Educational Psychology, 105(3), 805-820. https://doi.org/10.1037/a0032583

Künsting, J., Neuber, V. \& Lipowsky, F. (2016). Teacher self-efficacy as a long-term predictor of instructional quality in the classroom. European Journal of Psychology of Education, 31(3), 299-322. https://doi.org/10.1007/s10212-015-0272-7

Kyriakides, L., Creemers, B.P.M. \& Antoniou, P. (2009). Teacher behaviour and student outcomes: Suggestions for research on teacher training and professional development. Teaching and Teacher Education, 25(1), 12-23. http://dx.doi.org/10.1016/j.tate.2008.06.001

Kyriakides, L., Creemers, B.P.M., Panayiotou, A., Vanlaar, G., Pfeifer, M., Cankar, G. \& McMahon, L. (2014). Using student ratings to measure quality of teaching in six European countries. European Journal of Teacher Education, 37(2), 125-143. https://doi.org/10.1080/ 02619768.2014.882311

Kaarstein, H., Nilsen, T. \& Blömeke, S. (2016). Lærerkompetanse. I O.K. Bergem, H. Kaarstein \& T. Nilsen (Red.), Vi kan lykkes i realfag. Resultater og analyser fra TIMSS 2015 (s. 97-119). Universitetsforlaget.

Kaarstein, H., Radišić, J., Lehre, A.-C., Nilsen, T. \& Bergem, O.K. (2020). TIMSS 2019. Kortrapport. Institutt for lærerutdanning og skoleforskning, Universitetet i Oslo.

Mathieu, J.E. \& Taylor, S.R. (2006). Clarifying conditions and decision points for mediational type inferences in Organizational Behavior. Journal of Organizational Behavior, 27(8), 10311056. https://doi.org/10.1002/job.406

McGarity Jr., J.R. \& Butts, D.P. (1984). The relationship among teacher classroom management behavior, student engagement, and student achievement of middle and high school science students of varying aptitude. Journal of Research in Science Teaching, 21(1), 55-61.

https://doi.org/10.1002/tea.3660210107 
Menard, S. (2008). Introduction: Longitudinal research design and analysis. I S. Menard (Red.), Handbook of longitudinal research: Design, measurement, and analysis (s. 3-12). Elsevier.

Minner, D.D., Levy, A.J. \& Century, J. (2010). Inquiry-based science instruction-what is it and does it matter? Results from a research synthesis years 1984 to 2002. Journal of Research in Science Teaching, 47(4), 474-496. https://doi.org/10.1002/tea.20347

Mullis, I.V.S. \& Martin, M.O. (Eds.). (2017). TIMSS 2019 Assessment Frameworks. Hentet fra Boston College: TIMSS \& PIRLS International Study Center website: https://timssandpirls.bc.edu/timss2019/frameworks/

Mullis, I.V.S., Martin, M.O., Foy, P., Kelly, D.L. \& Fishbein, B. (2020). TIMSS 2019 International Results in Mathematics and Science. Hentet fra Boston College: TIMSS \& PIRLS International Study Center website: https://timssandpirls.bc.edu/timss2019/international-results/

Muthén, L.K. \& Muthén, B.O. (1998-2017). Mplus User's Guide. Eighth Edition. Muthén \& Muthén.

Neumann, K., Kauertz, A. \& Fischer, H.E. (2012). Quality of Instruction in Science Education. I B.J. Fraser, K.G. Tobin \& C.J. McRobbie (Red.), Second International Handbook of Science Education (s. 247-258). Springer.

Nilsen, T. \& Bergem, O.K. (2020). Teacher Competence and Equity in the Nordic Countries. Mediation and moderation of the relation between SES and achievement. Acta Didactica Norden, 14(1), 26. https://doi.org/10.5617/adno.7946

Nilsen, T. \& Gustafsson, J.-E. (2014). School emphasis on academic success: exploring changes in science performance in Norway between 2007 and 2011 employing two-level SEM. Educational Research and Evaluation, 20(4), 308-327.

Nilsen, T. \& Gustafsson, J.-E. (Red.). (2016). Teacher Quality, Instructional Quality and Student Outcomes. Relationships Across Countries, Cohorts and Time (vol. 2). Springer Open.

Nilsen, T. \& Kaarstein, H. (2016). TIMSS og statistiske metoder. I O.K. Bergem, H. Kaarstein \& T. Nilsen (Red.), Vi kan lykkes i realfag. Resultater og analyser fra TIMSS 2015 (s. 178-199). Universitetsforlaget.

Nilsen, T., Scherer, R. \& Blömeke, S. (2018). The relation of science teachers' quality and instruction to student motivation and achievement in the 4th and 8th grade: A Nordic perspective. I Nordic Council of Ministers (Red.), Northern Lights on TIMSS and PISA 2018 (s. 61-93). Nordic Council of Ministers 2018.

Nilsen, T., Scherer, R., Gustafsson, J.-E., Teig, N. \& Kaarstein, H. (2020). Teachers' Role in Enhancing Equity-A Multilevel Structural Equation Modelling with Mediated Moderation. I T. S. Frønes, A. Pettersen, J. Radišić \& N. Buchholtz (Red.), Equity, Equality and Diversity in the Nordic Model of Education (s. 173-196). Springer International Publishing.

Nordgård Vik, F., Nilsen, T. \& Øverby, N.C. (i trykk). The importance of sufficient sleep and breakfast intake for student cognitive outcomes - triangulation across time and subject domains among students and teachers in TIMSS. Scandinavian Journal of Educational Research.

Oliver, R.M., Wehby, J.H. \& Reschly, D.J. (2011). Teacher classroom management practices: effects on disruptive or aggressive student behavior. Campbell Systematic Reviews, 7(1), 1-55. https://doi.org/10.4073/csr.2011.4

Perlic, B. (2019). Lorerkompetanse i grunnskolen. Hovedresultater 2018/2019 (vol. Rapporter 2019/18). Statistisk sentralbyrå. 
Postholm, M.B. (2012). Teachers' professional development: a theoretical review. Educational Research, 54(4), 405-429. https://doi.org/10.1080/00131881.2012.734725

Praetorius, A.K., Grünkorn, J. \& Klieme, E. (2020). Towards developing a theory of generic teaching quality: origin, current status, and necessary next steps regarding the three basic dimensions model. Zeitschrift für Pädagogik, 66(1), 15-36.

Praetorius, A.K., Klieme, E., Herbert, B. \& Pinger, P. (2018). Generic dimensions of teaching quality: the German framework of Three Basic Dimensions. ZDM, 50(3), 407-426.

https://doi.org/10.1007/s11858-018-0918-4

Puthenpura, S. \& Sinha, N.K. (1986). Modified maximum likelihood method for the robust estimation of system parameters from very noisy data. Automatica, 22(2), 231-235.

https://doi.org/10.1016/0005-1098(86)90085-3

Quin, D., Hemphill, S.A. \& Heerde, J.A. (2017). Associations between teaching quality and secondary students' behavioral, emotional, and cognitive engagement in school. Social Psychology of Education, 20(4), 807-829. https://doi.org/10.1007/s11218-017-9401-2

Rampersaud, G.C., Pereira, M.A., Girard, B.L., Adams, J. \& Metzl, J.D. (2005). Breakfast habits, nutritional status, body weight, and academic performance in children and adolescents. Journal of American Diet Association, 105(5), 743-760. https://doi.org/10.1016/j.jada.2005.02.007

Rowan, B., Correnti, R. \& Miller, R.J. (2002). What Large-Scale Survey Research Tells Us About Teacher Effects on Student Achievement: Insights from the Prospects Study of Elementary Schools. Teachers College Record, 104(8), 1525-1567.

Samdal, O., Mathisen, F.K.S., Torsheim, T., Diseth, Å.R., Fismen, A.-S., Larsen, T.M., Wold, B. \& Årdal, E. (2016). Helse og trivsel blant barn og unge - Resultater fra den landsrepresentative spørreundersøkelsen «Helsevaner blant skoleelever. En WHO-undersøkelse i flere land». HEMILSenteret, Universitetet i Bergen. Hentet fra http://hdl.handle.net/1956/13072

Schmidt, R.E. \& Van der Linden, M. (2015). The Relations Between Sleep, Personality, Behavioral Problems, and School Performance in Adolescents. Sleep Medicine Clinics, 10(2), 117-123. https://doi.org/10.1016/j.jsmc.2015.02.007

Seidel, T. \& Shavelson, R.J. (2007). Teaching Effectiveness Research in the Past Decade: The Role of Theory and Research Design in Disentangling Meta-Analysis Results. Review of Educational Research, 77(4), 454-499. https://doi.org/10.3102/0034654307310317

Stea, T.H., Knutsen, T. \& Torstveit, M.K. (2014). Association between short time in bed, health-risk behaviors and poor academic achievement among Norwegian adolescents. Sleep Medicine, 15(6).

Stea, T.H. \& Torstveit, M.K. (2014). Association of lifestyle habits and academic achievement in Norwegian adolescents: a cross-sectional study. BMC Public Health, 14(1), 829. https://doi.org/10.1186/1471-2458-14-829

Sørlie, M.-A. \& Ogden, T. (2014). Mindre problematferd i skolen? - Lærervurderinger i et 10-års perspektiv. Norsk Pedagogisk Tidsskrift, 98(3), 190-202. https://doi.org/10.18261/ISSN15042987-2014-03-05

Tatto, M.T., Schwille, J., Senk, S., Ingvarson, L., Rowley, G., Peck, R., Bankov, K., Rodriguez, M., Reckase, M. (2012). Policy, Practice, and Readiness to Teach Primary and Secondary Mathematics in 17 Countries: Findings From The IEA Teacher Education and Development Study in Mathematics (TEDS-M). Amsterdam: International Association for the Evaluation of Educational Achievement (IEA). 
Timperley, H., Wilson, A., Barrar, H. \& Fung, I. (2007). Teacher professional learning and development. Best Evidence Synthesis Iteration (BES). Ministry of Education.

van Tartwijk, J. \& Hammerness, K. (2011). The neglected role of classroom management in teacher education. Teaching Education, 22(2), 109-112. https://doi.org/10.1080/ 10476210.2011.567836

Voss, T., Kleickmann, T., Kunter, M. \& Hachfeld, A. (2013). Mathematics Teachers' Beliefs. I M. Kunter, J. Baumert, W. Blum, U. Klusmann, S. Krauss \& M. Neubrand (Red.), Cognitive Activation in the Mathematics Classroom and Professional Competence of Teachers (vol. 8, s. 249271). Springer US.

Wagner, W., Göllner, R., Werth, S., Voss, T., Schmitz, B. \& Trautwein, U. (2016). Student and teacher ratings of instructional quality: Consistency of ratings over time, agreement, and predictive power. Journal of Educational Psychology, 108(5), 705-721. https://doi.org/10.1037/ edu0000075

Wang, M.-T. \& Degol, J.L. (2014). Staying Engaged: Knowledge and Research Needs in Student Engagement. Child Development Perspectives, 8(3), 137-143. https://doi.org/10.1111/ cdep. 12073

Wang, M.-T. \& Degol, J.L. (2016). School Climate: a Review of the Construct, Measurement, and Impact on Student Outcomes. Educational Psychology Review, 28(2), 315-352. https://doi.org/ 10.1007/s10648-015-9319-1

Wayne, A.J. \& Youngs, P. (2003). Teacher Characteristics and Student Achievement Gains: A Review. Review of Educational Research, 73(1), 89-122. https://doi.org/10.3102/ 00346543073001089

Yin, L. \& Fishbein, B. (2020). Creating and Interpreting the TIMSS 2019 Context questionnaire Scales. I M.O. Martin, M. von Davier \& I.V.S. Mullis (Red.), Methods and Procedures: TIMSS 2019 Technical Report. Hentet fra Boston College, TIMSS \&PIRLS International Study Center website: https://timssandpirls.bc.edu/timss2019/methods/chapter-16.html

Ødegaard, M., Kjærnsli, M., Karlsen, S., Kersting, M., Lunde, M.L.S., Olufsen, M. \& Sæleset, J. (2021). Tett på naturfag i klasserommet. LISSI-Rapport (2018-2020). Institutt for lærerutdanning og skoleforskning (UiO) og Norges arktiske universitet (UiT). 